\title{
Electron beam damage during testing of wood in the SEM
}

\author{
Hoffmeyer, P.; Hanna, R. B.
}

Publication date:

1988

Document Version

Publisher's PDF, also known as Version of record

Link back to DTU Orbit

Citation $(A P A)$ :

Hoffmeyer, P., \& Hanna, R. B. (1988). Electron beam damage during testing of wood in the SEM. Technical University of Denmark, Department of Civil Engineering.

\section{General rights}

Copyright and moral rights for the publications made accessible in the public portal are retained by the authors and/or other copyright owners and it is a condition of accessing publications that users recognise and abide by the legal requirements associated with these rights.

- Users may download and print one copy of any publication from the public portal for the purpose of private study or research.

- You may not further distribute the material or use it for any profit-making activity or commercial gain

- You may freely distribute the URL identifying the publication in the public portal

If you believe that this document breaches copyright please contact us providing details, and we will remove access to the work immediately and investigate your claim. 


\section{Electron Beam Damage During Testing} of Wood in the SEM

$$
\begin{array}{r}
\text { P. Hoffmeyer } \\
\text { R.B.Hanna }
\end{array}
$$

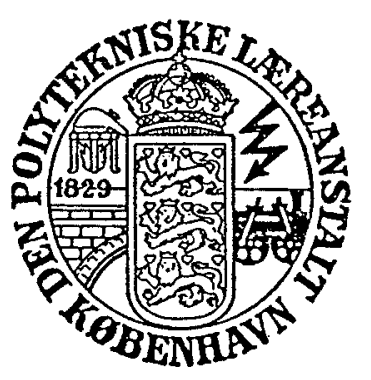

TECHNICAL UNIVERSITY OF DENMARK DEPARTMENT OF CIVIL ENGINEERING 
Technical note

\section{ELECTRON BEAM DAMAGE DURING TESTING OF WOOD IN THE SEM}

\section{P.Hoffmeyer, Building Materials Laboratory,}

Technical University of Denmark

R.B.Hanna, College of Environmental Science and Forestry, State University of New York, Syracuse

SUMMARY: During the course of compression testing wood in the SEM a highly brittle failure is observed. Such behavior has earlier been ascribed to the high vacuum of the SEM and the resultant low moisture content of the wood $(1,2,3)$. The results of the present investigation however, show that the brittleness is caused by electron beam damage. The failure morphology resembles that of gamma-irradiated wood (4). Although electron beam damage may be reduced, it can never be completely avoided. Caution is therefore to be exercised in the interpretation of results of such experiments.

MATERIAL AND METHODS: Specimens of spruce (Picea abies), approximately $1 \times 4 \times 4 \mathrm{~mm}$ with a necked down cross section of $1 \times 1 \mathrm{~mm}$ at the middle were conditioned. They were then taken to failure in compression parallel to grain at a constant rate of loading resulting in a time to failure of the order of 5-20 minutes depending on the ultimate strength. Four specimens were tested

Table 1 Conditions for mechanically tested specimens

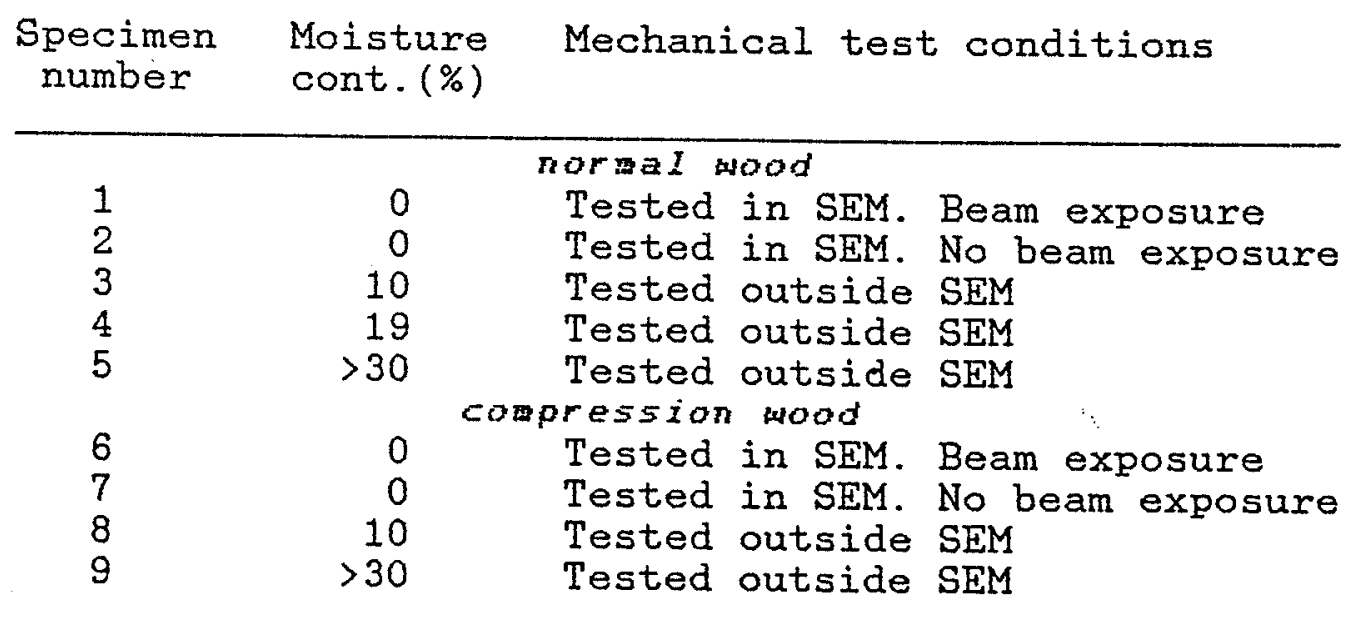


in the SEM after having been exposed to a vacuum of $10^{-5}$ Torr for 24 hours. The remaining 5 specimens were tested outside the SEM at room temperature. Test conditions are given in Table 1 . The backscattered electron imaging was used while mechanically testing specimens nos. 1 and 6 . During loading, the electron beam was moved continously across the potential failure zone while using a magnification of 900 times. Consequently, each $0.1 \times 0.1 \mathrm{~mm}$ area of this zone was exposed to the electron beam for an average of 2 minutes. The secondary electron imaging was used after failure and coating of the specimens. Accelerating voltage was $20 \mathrm{kV}$.

RESULTS: Micrographs of failures showed a distinct difference in morphology of the failure depending on whether or not specimens had been exposed to the electron beam during the compression testing. Figures 1 and 2 show the glassy fracture of wood exposed to the electron beam as opposed to the ductile folding of the cell walls exposed to vacuum but not to the electron beam (Figure 3). The ductility of the latter is clearly illustrated in Figure 4, which shows the result of a gradual separation of an S2-wall, whereby bundles of microfibrils are bent and subsequently stretched with no signs of brittleness. An equally significant difference in failure morphology for exposed- and unexposed wood was found for the two dry specimens of compression wood. There was found no evidence of any significant brittleness for unexposed wood of different moisture content levels.

(1)Kyanka, G. 1976: Proc. 2nd. Int'1 Cong. Mechanical Behavior of Materials:1354-1357. (2)Aiuchi, T.; Ishida,S. 1978: Mokuzai Gakkaishi 24(7):507-510. (3)Bariska, M. 1985: Proc. CSIR Symposium, Vol.1. (4) Ifju, G. 1964: For. Prod. J. 14:366-372. 
Fig. 1 Compression failure of spruce exposed to elec tron beam during testing

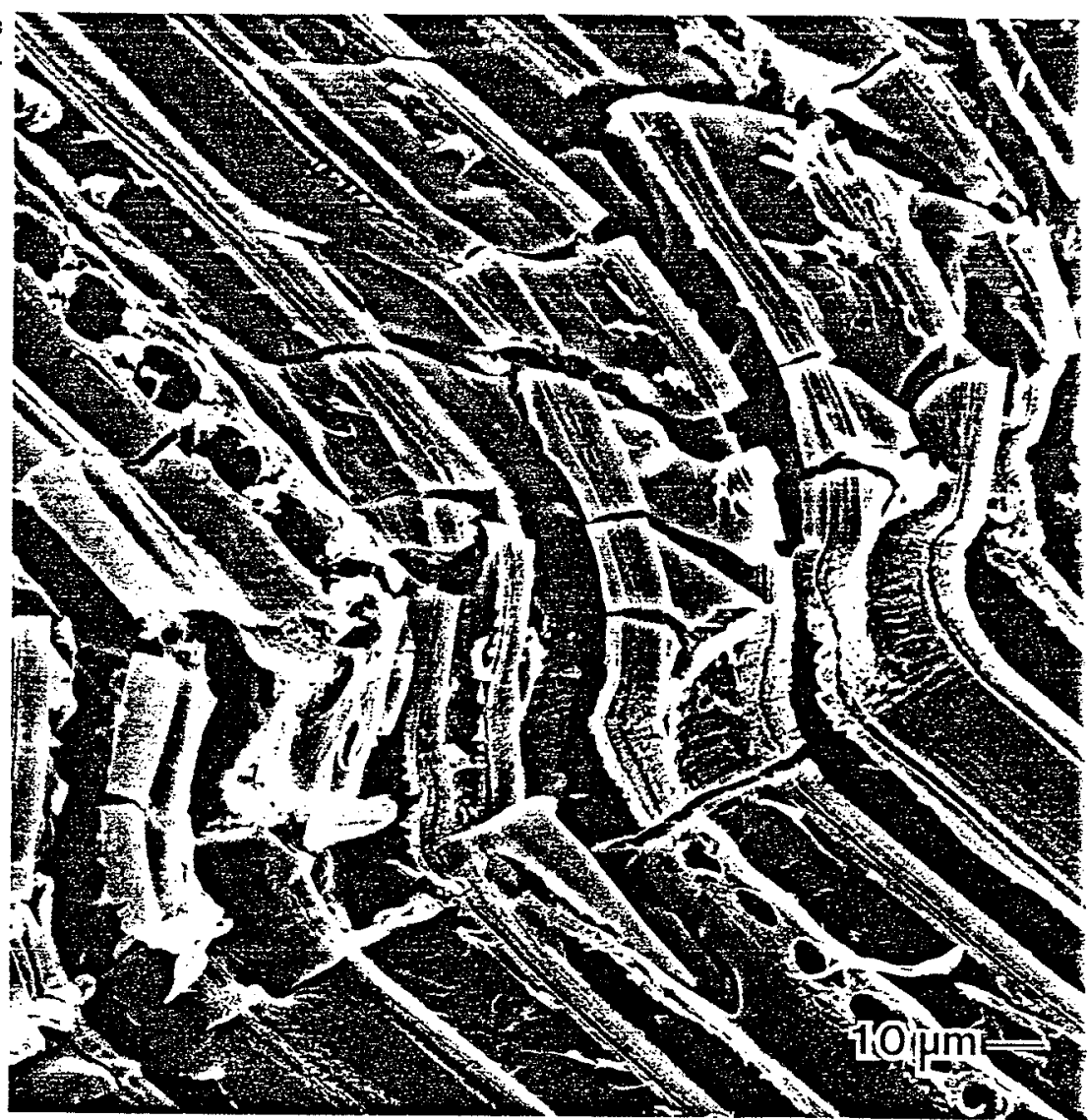

Fig. 2 Compression failure of spruce exposed to electron beam during testing.

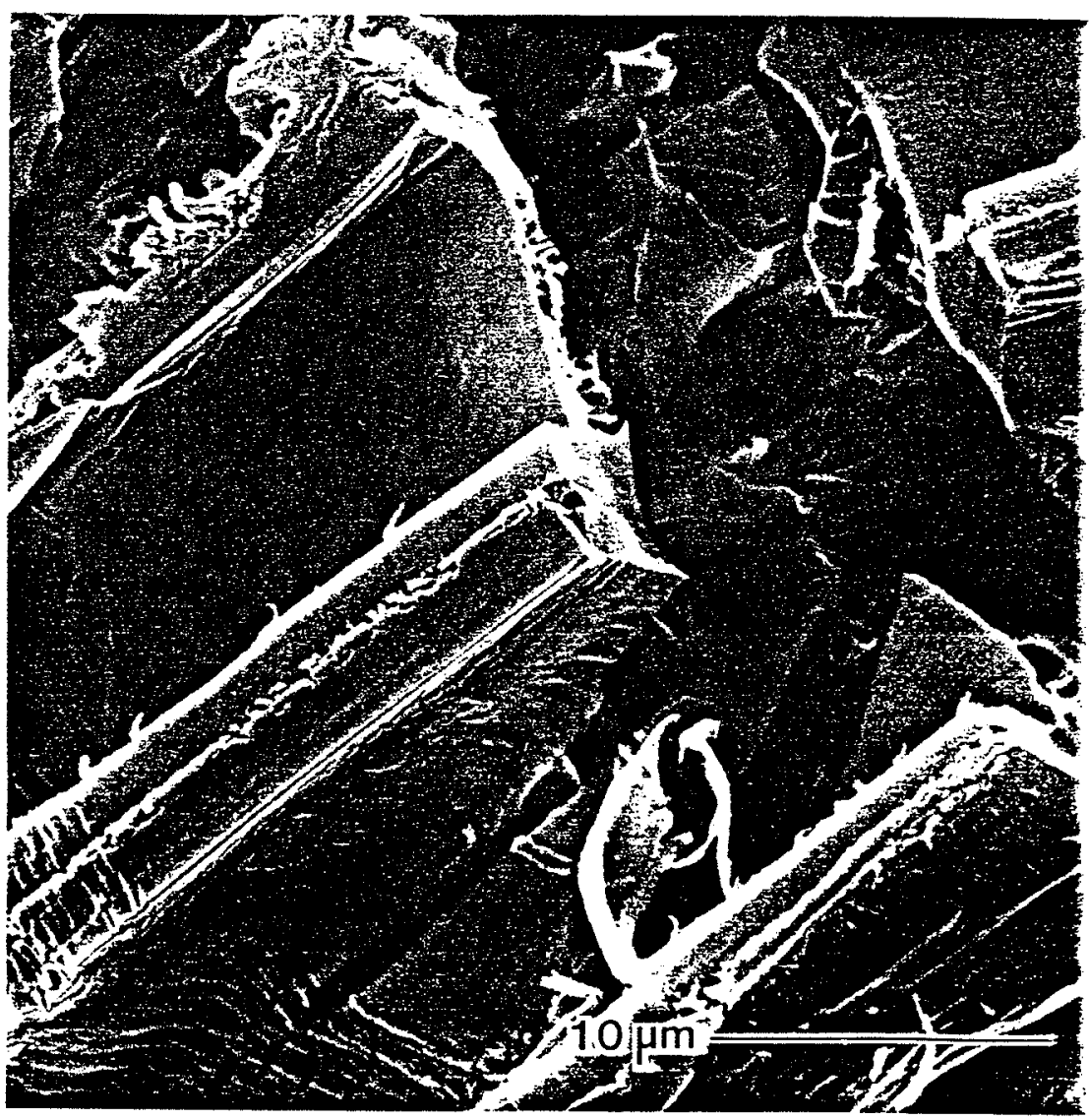


Eig. 3 Compression failure of spruce tested in vacuum but not exposed to electron beam during testing.

Fig. 4 Detail of Figure 3 showing the result of a gradual separation of cell wall elements.
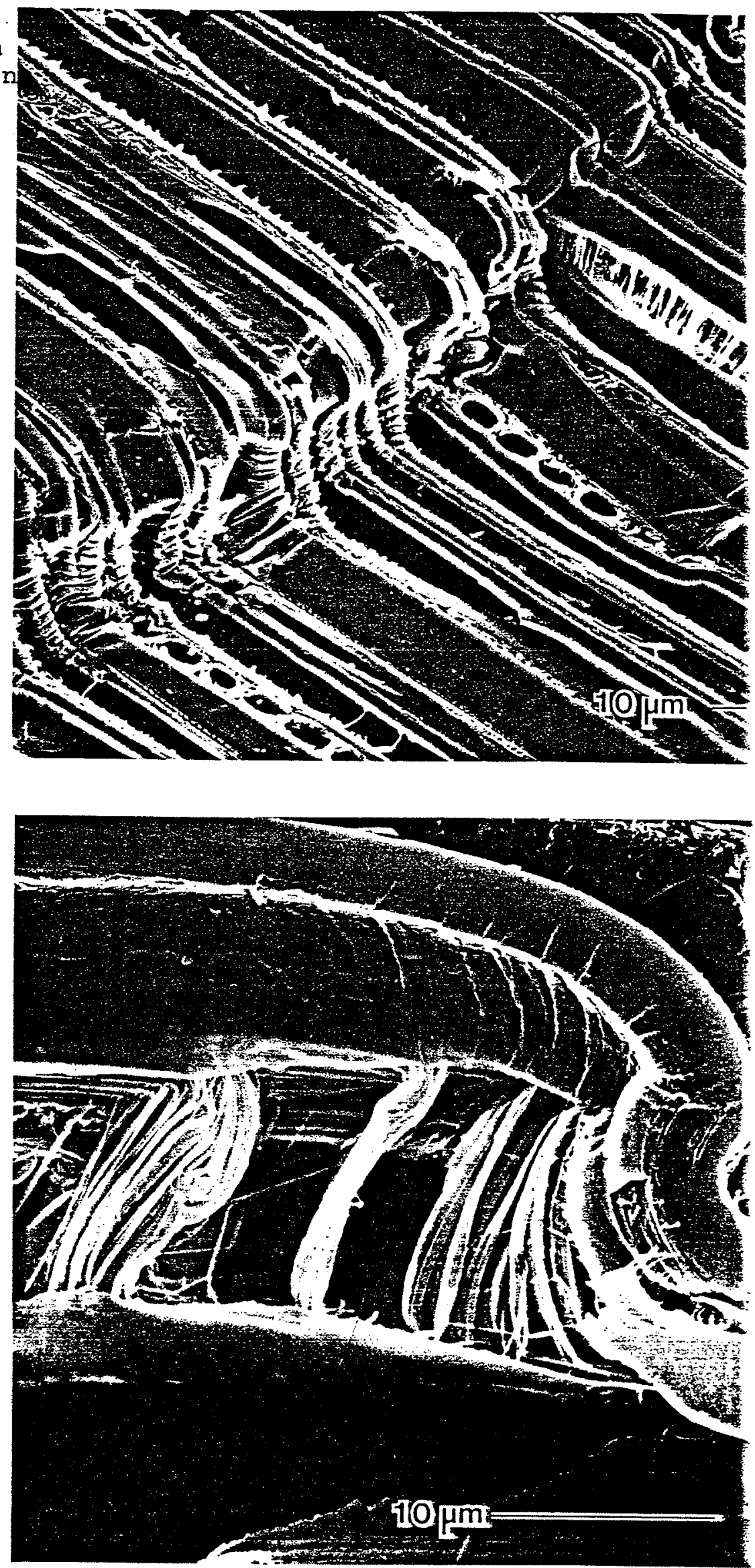